Int. J. Dev. Biol. 53: 69-79 (2009)

doi: $10.1387 / \mathrm{ijdb} .082682 \mathrm{hn}$

\title{
Transcriptional regulation by Pax3 and TGF $\beta 2$ signaling: a potential gene regulatory network in neural crest development
}

\author{
HIROMICHI NAKAZAKI 1,a, d ${ }^{2}$, YUEH-WEI SHEN ${ }^{1, d}$, BETH YUN ${ }^{1, b}$, ANVESH REDDY ${ }^{1, c}$, VARUN KHANNA ${ }^{1}$, \\ BARBARA MANIA-FARNELL ${ }^{2}$, SHUNSUKE ICHI ${ }^{1}$, DAVID G. MCLONE${ }^{1}$, TADANORI TOMITA ${ }^{1}$ \\ and C. SHEKHAR K. MAYANIL*,1
}

\begin{abstract}
${ }^{1}$ Laboratory of Neural Tube Research, Department of Pediatric Neurosurgery, Children's Memorial Research Center and Northwestern University Feinberg School of Medicine, Chicago, IL and '2Department of Biology, Purdue University at Calumet, Hammond, IN, USA
\end{abstract}

\begin{abstract}
Pax3 regulates neural crest cell migration and is critical during neural crest development. TGF $\beta$ s modify neural crest cell migration and differentiation. TGF $\beta 2$ nullizygous embryos (TGF $\beta 2 \%-\mathrm{Pax}^{+/+}$) display open neural tube and bifid spine, whereas in wild type embryos the neural tube is closed. In previous work, we have demonstrated that Pax3 regulates TGF $\beta 2$ by directly binding to cis-regulatory elements on its promoter. In this study, we found that the TGF $\beta 2$ nullizygous phenotype can be reversed to the wild type phenotype by down-regulating one allele

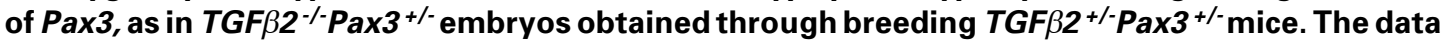
in this paper suggest that Pax3 and TGF $\beta 2$ interact in a coordinated gene regulatory network, linked by common downstream effector genes, to bring about this phenotypic reversal. Downstream effectors may include Hes1, Ngn2 and Sox9, as well as other genes involved in neuronal differentiation.
\end{abstract}

KEY WORDS: Hes1, Ngn2, Sox9, epithelial-to-mesenchymal transformation

\section{Introduction}

In 1954, Auerbach observed that developmental defects in homozygous Splotch embryos are associated with neural crest cell deficiency. In the homozygous condition the Splotch $(S p)$ mutation is lethal by embryonic day 13.5. These embryos display defects in neural tissue, neural crest derivatives, and limb musculature. Splotch heterozygotes exhibit defects in neural crest derivatives, which result in white patches on their bellies caused by defective development of neural crest derived melanocytes (Foy et al., 1990). Chromosome localization in conjunction with the spatio-temporal tissue distribution of Pax3 transcripts and tissues affected in Spmutants led to direct experimental analysis demonstrating that Splotchand Pax3are the same gene (Epstein et al., 1991; Goulding et al., 1993) and the homozygous Splotch condition is $\mathrm{Pax}^{\prime-}$. These studies show that $\mathrm{Pax} 3$ has a regulatory role in neural crest development.

Other studies also indicate that $\mathrm{Pax} 3$ has a role in regulating neurogenesis in neural crest derived precursor cells. Goulding et al. (1991) demonstrated Pax3 expression in a population of migrating neural crest cells (NCCs) that contribute to the dorsal root ganglia and cephalic mesenchyme. In a separate study Li et al. (1999) found that Pax3 replacement rescued neural tube closure and other neural crest related anomalies in $S p$ mutants. This group produced transgenic mice that over expressed Pax3 in neural tube and neural crest. They then took Pax3 overexpressing transgenic lines and crossed them with heterozygous Splotchmice. Transgenic heterozygous Splotch mice were identified, backcrossed to Splotch heterozygotes and examined at E13.5. All transgenic Splotch homozygous embryos had normal closed neural tubes in comparison to non-transgenic Splotch homozygous embryos, all of which displayed neural tube defects in the lumbrosacral region and in some cases exencephaly. More

Abbreviations used in this paper: NCC, neural crest cell; ngn, neurogenin. *Address correspondence to: C. S. K. Mayanil. Laboratory of Neural Tube Research, Developmental Biology Program, Childrens Memorial Research Center,
Box \# 204, 2430 N Halsted Street, Chicago, IL 60614. Fax: 773-755-6385. e-mail address: smayanil@northwestern.edu

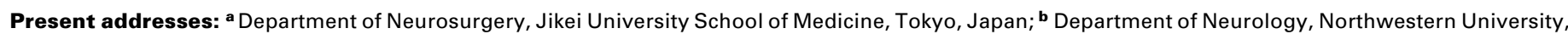

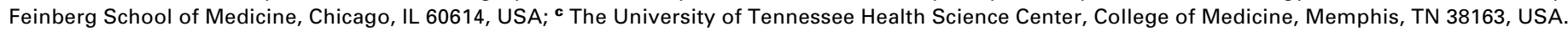

Note d: These authors contributed equally to the work.

Accepted: 5 June 2008. Published online: 5 December 2008. Edited by: Angie Rizzino. 
recently, our lab (Nakazaki et al., 2008) investigated the mechanism by which $\mathrm{Pax} 3$ regulates neurogenesis in neural crest derived precursor cells. We found that Pax 3 regulates two bHLH transcription factor genes, Hairy and enhancer of split homolog1 (Hes1) and Neurogenin2 (Ngn2). Hes1 and other Hes genes prevent premature neurogenesis (Hirata et al., 2001) and Ngn2 plays a critical role in sensory neurogenesis (Lo et al., 2002).

TGF $\beta$ s are essential for normal neural crest development (Nie et al., 2008). Loss of TGF $\beta$ signaling causes decreased chondrocyte proliferation and premature differentiation of cartilage to bone (Hosokawa etal., 2007). Expression of Msx2, a critical factor in the formation of the dorso-ventral axis, is diminished in Tgfbr2 mutants (Hosokawa et al., 2007). The TGF $\beta$ intracellular effector Smad3 regulates neuronal differentiation and cell fate specification in the developing spinal cord. Additionally, Smad3-mediated TGF $\beta$ activity promotes neurogenesis, cell-cycle exit and lateral migration of neuroepithelial progenitor cells (García-Campmany and Martí, 2007). Nie et al. (2008) investigated the role of Smad4, a TGF $\beta / B M P$ signaling intermediate, in the development of NCCs. A Cre/loxP system was used to specifically disrupt Smad4 in NCCs. Expression of multiple genes, including $M s x 1,2, A p-2 \alpha$, Pax3, and Sox9, which play critical roles in NCC development, was down regulated by Smad4 disruption. Mutant mice died at mid-gestation due to severe molecular defects.

TGFB2-null embryos show open caudal neural tube with unfused spine (Sanford et al., 1997), similar to Pax3\%- embryos. Work from our lab established a link between Pax3 and TGF $\beta 2$ (Mayanil et al., 2006). Pax3 regulates the TGFR2 promoter by binding to its cis-regulatory elements, and TGF 2 expression is diminished in $\mathrm{Pax}^{/-}$embryos. Thus a regulatory relationship exists between Pax3 and TGF $\beta 2$ (Mayanil et al., 2006).

In the present study we further examined the relationship between Pax3 and TGF $\beta 2$ in neural crest development. We found that the open neural tube and bifid spine observed in $T G F \beta^{-/}$ $\mathrm{Pax}^{+/+}$embryos was significantly reversed by down-regulating

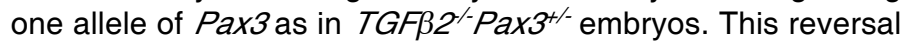
may be due to Pax3 and TGF $\beta 2$ working together in a regulated fashion to affect the actions of downstream target genes important in neural crest development.

\section{Results}

\section{Incidence of neural tube defects in embryos bred from TGF $\beta 2^{+/}$ -Pax ${ }^{+/-}$double heterozygous mice: phenotypic reversal in TGFß2 null embryos by Pax3 down-regulation}

In order to investigate how Pax3 and TGF $\beta$ interact in neural crest development we first bred TGF $\beta 2^{+/-P a x} 3^{+/}$double heterozygous mice and examined the phenotypes of resulting offspring. Table 1 compares Mendelian projections for breeding T GF $\beta 2^{\text {H- }}$ $\mathrm{Pax}^{+{ }^{+-}}$double heterozygotes, with live births at post natal day 0 (P0). Live births were seen in all genotypes where there was at least one copy of TGF 2 and Pax3. The table also shows the observed frequency of the open neural tube phenotype in E10.0 embryos bred from TGF $32^{+/-} \mathrm{Pax}^{+/-}$double heterozygotes. Approximately $4 \%$ (10/254 embryos) of the wild type TGF $\beta 2^{+/}$ ${ }^{+} \mathrm{Pax}^{+/+}$embryos showed neural tube defects (NTDs), which was not statistically significant. No NTDs were observed in TGF $\beta 2^{\text {t/- }}$ $\mathrm{Pax}^{+/+}$embryos. Open NTDs were seen in 85\% (24 out of 28 ) of the TGF $2^{/-} \mathrm{Pax}^{+/+}$embryos, however only $36 \%$ (9 out of 25 ) of the TGFP2/-Pax3+/- embryos exhibited open NTDs. The difference seen between the latter two groups is statistically significant $(p=0.0002)$ as analyzed by Fisher's Exact test (Prism v.4.0

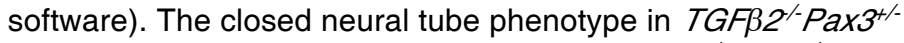
embryos can be seen in Fig. 1. E10.0 TGF $\beta 2^{/-P a x 3^{+/+}}$and TGFB2/- $\mathrm{Pax}^{+/-}$embryos did not exhibit additional external abnormalities. However Sanford etal.,1997) have shown that TGF 2 null mice exhibit perinatal mortality and a wide range of developmental defects. These include cardiac, lung, craniofacial, limb, spinal column, eye, inner ear and urogenital defects. The developmental processes commonly involved in the affected tissues include epithelial-mesenchymal interactions, cell growth, extracellular matrix production and tissue remodeling. In addition, many affected tissues have neural crest-derived components and simulate neural crest deficiencies (Sanford et al., 1997).

In the type of study done here there is a possibility of a partial rescue of the TGF 2 null phenotype due to a mixed genetic

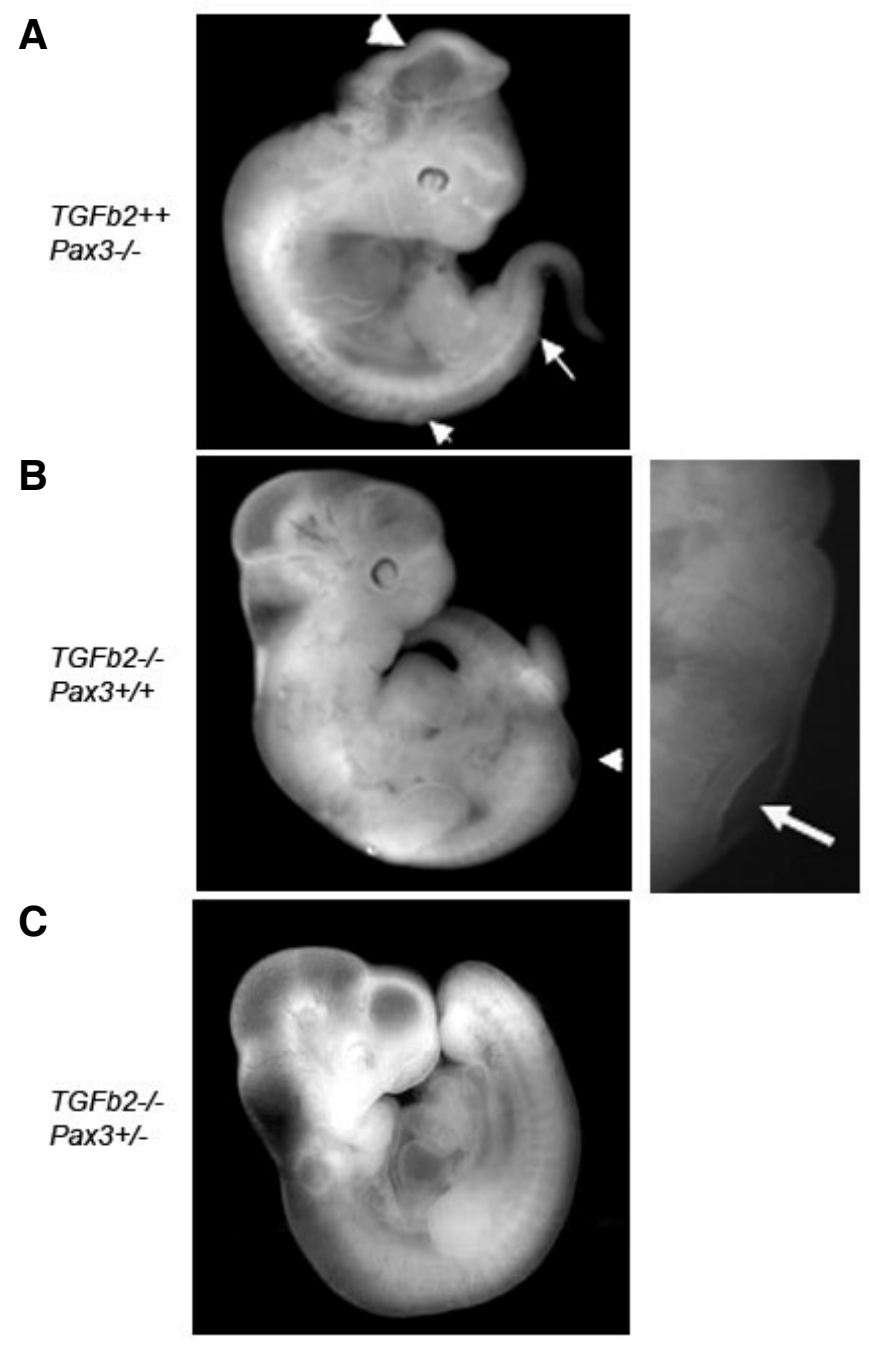

Fig. 1. Phenotypic recovery in TGF $\beta 2$ nullizygous embryos by $\boldsymbol{P a x} 3$ down-regulation. (A) TGF $\beta 2^{+/+} P a \times 3^{--}$embryo with open cranial and

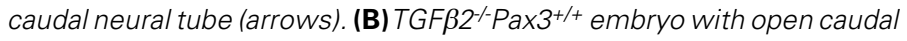
neural tube (arrow). Enlarged version of the open neural tube in (B) on the

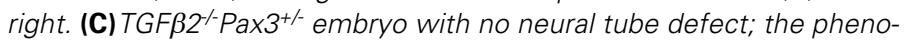
type here is comparable to wild type (TGF $\left.\beta^{+/+} \mathrm{Pax} 3^{+/+}\right)$. 
background. To rule out possible contributions of background effects on the partial rescue of the TGF 2 2 null phenotype, we took TGF $32^{+/-}$Pax $3^{\text {t- }}$ double heterozygous females from the $F 1$ generation of the original cross and back-crossed these with black Swiss3T3 males for 6 generations. The results demonstrated that even in a mixed background, TGF $32^{/-} \mathrm{Pax}^{+/+}$embryos showed open neural tube phenotype which was reversed in TGF $32^{-/} P a \times 3^{+/-}$embryos. These results show that: (a) Pax3down regulation decreases the incidence of open neural tube in TGFB2null embryos; (b) Downregulation of Pax3 in TGF 2 null embryos does not totally rescue these embryos, as no live $T G F \beta 2^{\prime}$ $\mathrm{Pax}^{+/-}$births were observed. The lack of live births is not surprising as TGF $\beta 2$ null genotype produces a wide range of developmental defects, in addition to open caudal neural tube with unfused spine (Sanford et al., 1997); (c) Down-regulating TGF 2 does not the rescue the open neural tube phenotype in $\mathrm{Pax}^{-/}$embryos.

\section{Hes1, Ngn2 and Sox9 expression levels in vivo}

Based on the above observations and earlier work from our laboratory showing $\mathrm{Pax} 3$ regulation of $\mathrm{T} G F \beta 2$ in migrating NCCs (Mayanil et al., 2006) we surmised that $P a x 3$ and TGF $\beta 2$ regulated common effecter genes involved in neural crest development. The significant reversal from the open neural tube phenotype seen in

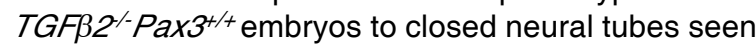

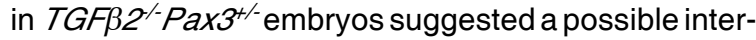
play between Pax3 and TGF $\beta 2$, where these two may act in a reciprocal fashion to maintain levels of some common downstream genes in proper balance.

To begin elucidating the relationship between Pax3 and TGF 32 we investigated Hes1, Ngn2 and Sox9 expression levels in embryos with the following 6 genotypes: TGF $32^{+/+} \mathrm{Pax}^{+/+}$, TGF $\beta 2^{-1}-\mathrm{Pax}^{+/+}, \mathrm{TGF}^{+2^{+/}}$

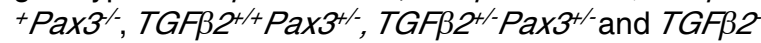
/Pax3"/- We choose Hes1 and Ngn2 because these molecules are critical in neurogenesis and $\mathrm{Pax} 3$ regulates Hes 1 and $\mathrm{Ngn} 2$ by directly binding to cis-regulatory elements on their promoters (Nakazaki et al., 2008). Moreover, Hes 1 is down-regulated by TGF $\beta$ (Zavadil et al., 2001; Blokzijl et al., 2003) and its expression oscillates with 2 hour periodicity during development (Hirata et al., 2002). Ngn2 expression is coincident with Pax 3 during neural tube closure and Ngn2 knockout embryos display neural tube defects (Fode et al., 1998). Additionally, down-regulation of Hes 1expression, which induces neural progenitor differentiation, leads to sustained up-regulation of Ngn2(Shimojo et al., 2008). Sox9was chosen because it regulates neural crest development (Cheung and Briscoe, 2003), and it is up-regulated by TGF $\beta$ (Zavadil et al., 2001) and down-regulated by Pax3 over-expression (Mayanil et al., 2001).

Whole mount in situ hybridization was done on E10.0 (30 somite stage) embryos, using digoxigenin labeled Hes 1(Fig. 2A), Ngn2(Fig. 2B) and Sox9riboprobes (Fig. 2C). Wildtype (TGF $2^{+/}$ ${ }^{+}$Pax $^{+/+}$) embryos expressed Hes 1 in dorsal neural tube (red arrow) and in migrating neural crest cells (yellow arrows) (Fig.

\section{A (Hes1 whole mount in situ hybridization)}

(i)

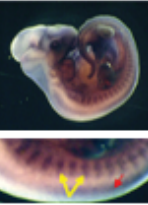

Pax3+/+
TGFb2+/+ (ii)

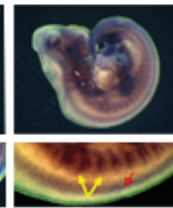

TGFb2-/

Pax3+/+ (iii)

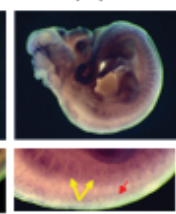

TGFb2+/+

Pax3-/- (iv)

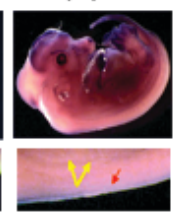

TGFb2+/+ Pax3+/- (v)

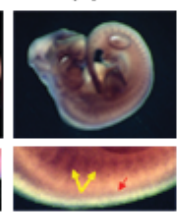

TGFb2+/Pax3+/- (vi)

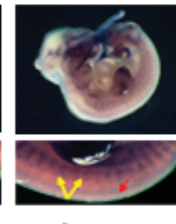

TGFb2-1

Pax3+/-

\section{B (Ngn2 whole mount in situ hybridization)}

(i)

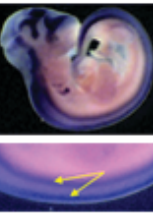

TGFb2+/+ Pax3+/+ (ii)

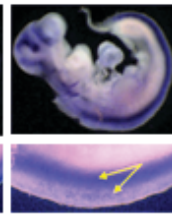

TGFb2- $\%$ Pax3+/+ (iii)

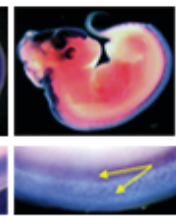

TGFb2+/+ Pax3-/ (iv)

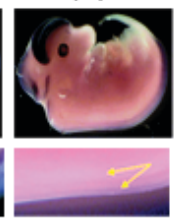

TGFb2+/+ Pax3+/- (v)

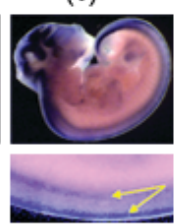

TGFb2+/Pax3+/- (vi)

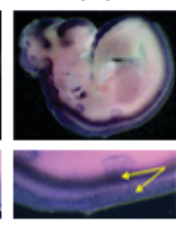

TGFb2-/-

Pax3+/-

\section{C (Sox9 whole mount in situ hybridization)}

(i)

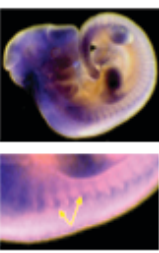

TGFb2+/+ $\mathrm{TGF}$
$\mathrm{Pa} 2+/++$ (ii)

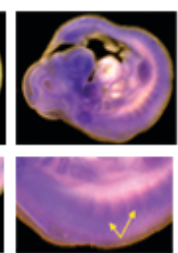

TGFb2-/ Pax $3+/+$ (iii)

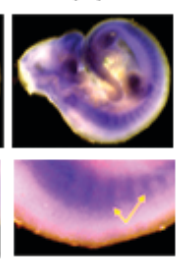

TGFb2+/+ Pax3-/ (iv)

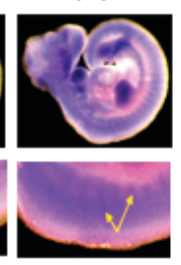

TGFb2+/+ Pax3+/ (v)

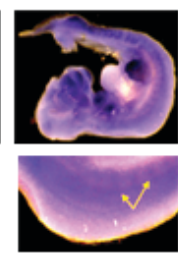

TGFb2+/-

Pax3+/- (vi)

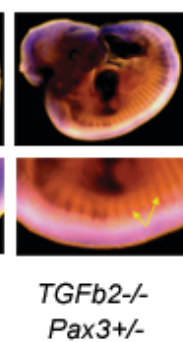

Fig. 2. Whole mount in situ hybridization. E10.0 (30 somite) embryos with the following genotypes: (i) TGF $\beta 2^{+/+} \mathrm{Pax} 3^{+/+}$, (ii) TGF $\beta 2^{--} \mathrm{Pax} 3^{+/+}$, (iii)TGF $\beta 2^{+/+} \mathrm{Pax} 3^{-1}$, (iv)

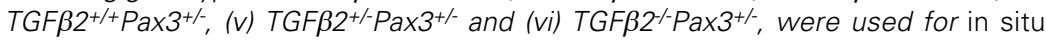
hybridization with digoxigenin-labeled murine Hes1, Ngn2 and Sox9 riboprobes. (A) Hes1 mRNA expression in embryonic NCCs. Yellow and red arrows represent Hes1 positive staining in migrating NCCs and neural tube respectively. (B) Ngn2 mRNA expression showing dorsal and ventral neural tube staining of Ngn2 transcripts. Yellow arrows point to dorsal and ventral neural tube regions. (C) Sox9 mRNA expression in embryonic NCCs. Yellow arrows indicate Sox9 positive migrating NCCs. In situ hybridization experiments for each genotype were done in quadruplicate, representative data is shown here. In situ hybridization using digoxigenin-labeled sense Hes1, Ngn2 and Sox9 riboprobes did not show staining (data not shown).

2Ai). Semi-quantification (Fig. 3) of our in situhybridization results with densitometry (total density 8 bit gray) showed a slight but insignificant increase in Hes 1 levels in TGFB2 $2^{1-}$ Pax $3^{+/+}$embryos in both the dorsal neural tube and migrating neural crest cells (Fig. 2A-ii) as compared with wild type embryos (Fig. 2A-i). Hes1 expression was down-regulated in both expression domains in

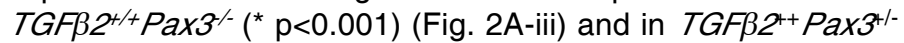
$\left.{ }^{* *} p<0.0005\right)$ embryos (Fig. 2A-iv). Expression was close to wild-

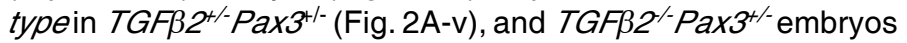
(Fig. 2A-vi). These studies suggest that both Pax3 and TGF $\beta 2$ play a role in regulating Hes 1 expression in the dorsal neural tube and migrating NCCs during embryonic development. 
TABLE 1

\section{PHENOTYPIC RECOVERY OF TGF $\beta 2$ NULLIZYGOUS EMBRYOS BY DOWN-REGULATING ONE ALLELE OF PAX3}

\begin{tabular}{|c|c|c|c|c|c|c|c|c|c|}
\hline Genotypes & $\begin{array}{l}\text { TGFB2+/+ } \\
\text { Pax3+/+ }\end{array}$ & $\begin{array}{l}\text { TGFß2+/- } \\
\text { Pax3+/+ }\end{array}$ & $\begin{array}{l}\text { TGF32-/- } \\
\text { Pax3+/+ }\end{array}$ & $\begin{array}{l}\text { TGF } 32+/+ \\
\text { Pax3+/- }\end{array}$ & $\begin{array}{l}\text { TGF } 32+/- \\
\text { Pax3+/- }\end{array}$ & $\begin{array}{l}\text { TGFB2-/- } \\
\text { Pax3+/- }\end{array}$ & $\begin{array}{l}\text { TGFß2+/+ } \\
\text { Pax3-/- }\end{array}$ & $\begin{array}{l}\text { TGFß2+/- } \\
\text { Pax3-/- }\end{array}$ & $\begin{array}{l}\text { TGF } 2 \text { 2- } \\
\text { Pax3\%- }\end{array}$ \\
\hline $\begin{array}{l}\text { Mendelian } \\
\text { Projection }\end{array}$ & $6.25 \%$ & $12.50 \%$ & $6.25 \%$ & $12.50 \%$ & $25 \%$ & $12.50 \%$ & $6.25 \%$ & $12.50 \%$ & $6.25 \%$ \\
\hline $\begin{array}{c}\text { Number of Live } \\
\text { BIRTHS }\end{array}$ & 235 live births & 110 live births & No live births & 88 live births & 125 live births & No live births & No live births & No live births & $\begin{array}{l}\text { No live } \\
\text { births }\end{array}$ \\
\hline $\begin{array}{l}\text { Frequency of open } \\
\text { neural tube in } \\
\text { E10.0 embryos }\end{array}$ & $\begin{array}{c}10 \text { out of } 245 \\
\text { embryos had NTD } \\
(4 \%)\end{array}$ & $\begin{array}{c}4 \text { out of } 190 \\
\text { embryos had NTD } \\
(2 \%)\end{array}$ & $\begin{array}{c}24 \text { out of } 28 \\
\text { embryos had NTD } \\
(85 \%)\end{array}$ & $\begin{array}{c}6 \text { out of } 188 \\
\text { embryos had NTD } \\
(3 \%)\end{array}$ & $\begin{array}{c}10 \text { out of } 55 \\
\text { embryos had NTD } \\
(18 \%)\end{array}$ & $\begin{array}{c}9 \text { out of } 25 \\
\text { embryos had NTD } \\
(36 \%) \\
(p=0.0002)\end{array}$ & $\begin{array}{c}28 \text { out of } 28 \\
\text { embryos had NTD } \\
(100 \%)\end{array}$ & $\begin{array}{c}32 \text { out of } 32 \\
\text { embryos had NTD } \\
(100 \%)\end{array}$ & $\begin{array}{c}5 \text { out of } 5 \text { embryos } \\
\text { were resorped } \\
(100 \%)\end{array}$ \\
\hline
\end{tabular}

\section{$\mathrm{p}=0.0002$}

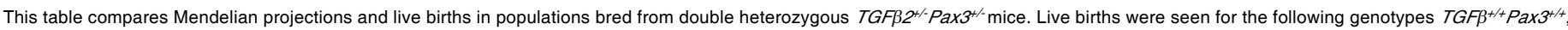

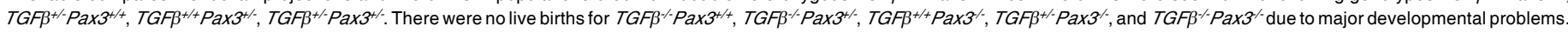

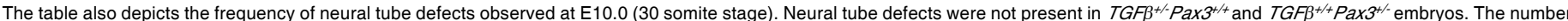

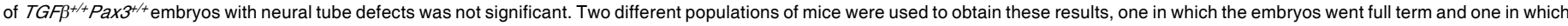

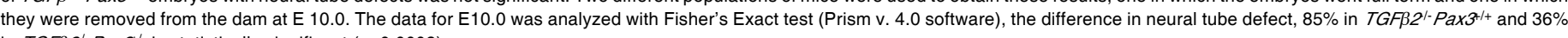
in $T G F B 2^{/-}$Pax ${ }^{+/-}$is statistically significant $(\mathrm{p}=0.0002)$.

In situ hybridization (Fig. 2B) using digoxigenin labeled Ngn2 riboprobe in $\mathrm{TGF} \beta 2^{+/+} \mathrm{Pax}^{+/+}$embryos (Fig. 2B-i) showed dorsal and ventral expression patterns consistent with earlier reports that"Ngn2 expression in dorsal and ventral spinal neural tube progenitor cells is regulated by distinct enhancers (Simmons et al., 2001). Semi-quantification (Fig. 3) of the in situhybridization results with densitometry (total density 8 bit gray) showed a significant decrease $(\$ p<0.0001)$ in $N g n 2$ expression in the dorsal neural tube, but a significant increase in $\mathrm{Ngn2}$ expression $(\S \S p<0.002)$ in the ventral neural tube of $T G F \beta 2^{-1}-P_{a x 3^{+/+}}$embryos

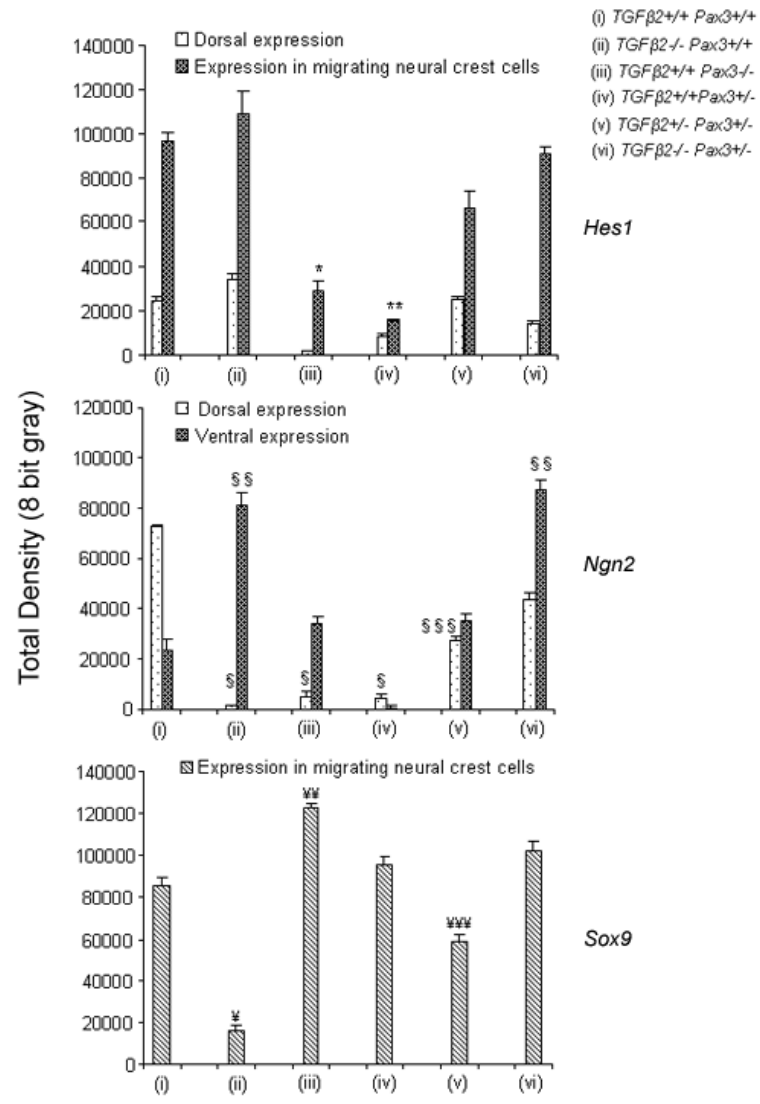

(Fig. 2B-ii) compared to wild type. TGF $\beta 2^{t /+} P a x 3^{/-}$embryos showed reduced $\mathrm{Ngn2}$ expression (Fig. 2B-iii) in the dorsal region. Ngn2expression was significantly reduced $\left(\S^{\S}<0.0001\right)$ in

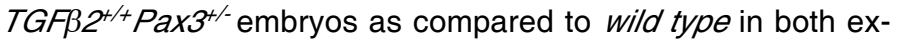
pression domains (Fig. 2B-iv). In double heterozygous embryos

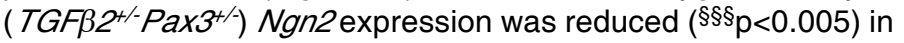
the dorsal region (Fig. 2B-v) as compared with wild typeembryos.

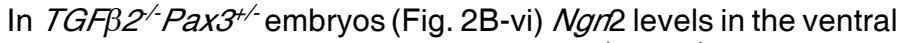

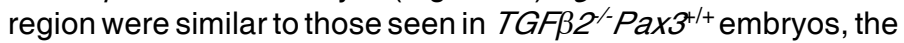
dorsal region however showed a tendency to recover toward levels seen in wild type. These observations indicate that Pax3 and TGF $\beta 2$ both play a role in regulating Ngn2 expression.

When digoxigenin labeled Sox9 riboprobe (Fig. 2C) was used for whole mount in situ hybridization, Sox9 positive staining was seen in migrating NCCs in TGF $\beta 2^{+/+} \mathrm{Pax}^{+/+}$embryos (Fig. $2 \mathrm{C}-\mathrm{i}$ ). Semi-quantification (Fig. 3) of the in situhybridization results with densitometry (total density 8 bit gray) showed a significant decrease $\left({ }^{*} \mathrm{p}<0.001\right)$ in Sox9 expression in TGF $32^{-1-P a x 3^{+/+}}(\mathrm{Fig}$. $2 \mathrm{C}$-ii) embryos as compared to wild type controls. TGF $2^{+/+}$Pax3 1- embryos showed an increase $(¥ \neq \mathrm{p}<0.005)$ in Sox9 expression (Fig. 2C-iii) compared with wild type. TGF $\beta 2^{+1+} P a x 3^{+/}$embryos showed a small insignificant increase in Sox9 expression (Fig. 2C-iv). Sox9 expression was significantly decreased in TGF $\beta 2^{+1}$ - $P a \times 3^{+/-}$embryos $\left({ }^{¥} ¥ \mathrm{p}<0.05\right)(2 \mathrm{C}-\mathrm{v})$. Staining in TGF $\beta 2^{/-} \mathrm{Pax}^{+/}$ - embryos (Fig. 2C-vi) was similar to the pattern seen in wild-type $\left(\right.$ TGF $\left.2^{+/+} \mathrm{Pax}^{+/ t}\right)$. These data suggest that Sox9 expression is

Fig. 3. Semi-quantification of digoxigenin-labeled Hes1, Ngn2 and Sox9 riboprobe staining using densitometry scanning (Open Lab program -Leica). Total density was determined from images scanned in 256 gray scale. The data is represented as the total density (8 bit gray), which is defined as the area multiplied by the mean of the relative densitometry units in the embryonic region under investigation. For Hes 1, the data is represented as total density ( 8 bit gray) of Hes 1 positive staining in dorsal neural tube and in migrating NCCs; ${ }^{*} p<0.001 ; * *$ $p<0.0005$, Student $T$ test). For Ngn2, the data is represented as total density (8 bit gray) of the dorsal and ventral Ngn2 positive staining; ( $\left.\right|^{\$}$ $p<0.0001, \xi \xi p<0.002,{ }^{\xi \xi \xi} p<0.005$, Student $T$ test). For Sox9, the data is represented as total density (8 bit gray) of the Sox9 positive staining in migrating NCCs; $¥ p<0.001 ; ¥ ¥ p<0.005 ; ¥ ¥ ¥ p<0.05$, Student $T$ test $)$. The values represent the average \pm SEM of 4 embryos for each genotype. 
regulated by Pax3 and TGF $\beta 2$ during embryonic development.

\section{TGF 32 effect on Pax3 regulation of Hes1, Ngn2 and Sox9 promoter activity}

The TGF $\beta 2$ intracellular effector phospho-Smad3 regulates neuronal differentiation and cell fate specification in the developing spinal cord (García-Campmany and Martí, 2007). To further examine the relationship between Pax3 and TGF $\beta 2$ we co-transfected DAOY cells with pcDNA3 or pcDNA3-Pax3 expression constructs, Hes1-luciferase (Fig. 4 A,B), Ngn2-luciferase (Fig. 5 A,B) or Sox9-luciferase (Fig. 6 A,B) promoter constructs, and Flag-Smad3 or Flag-DN-Smad3 (dominant negative Smad3) expression vectors. Transfected cells were then untreated or treated with $10 \mathrm{ng} / \mathrm{ml}$ human recombinant TGF $\beta 2(10 \mathrm{ng} / \mathrm{ml})$ for 6 hours. Luciferase activity was measured
48 hours after transfection.

Hes 1-promoter-luciferase and mutant constructs are fully described in our previous paper (Nakazaki et al., 2008). When pGL3 control vector, Hes-1-1uc, Hes 1 mut \#1 or Hes1 mut \#2 constructs were co-transfected with pcDNA3 in DAOY cells, neither Smad3 nor TGF $\beta 2$ affected promoter activity (Fig. 4A). When Hes 1-luc was co-transfected with pcDNA3-Pax3, with DN-Smad3 minus TGF $\beta 2$, there was a 7-8 fold increase in Hes 1 promoter activity in comparison to pcDNA3 transfection (Fig. 4B). Promoter activity did not increase significantly when Hes 1 mut1 or Hes 1 mut2 were co-transfected with pcDNA3-Pax3. These results agree with our previous work (Nakazaki et al., 2008). Pax3 mediated Hes1 promoter activity (DN-Smad3 minus TGF $\beta 2$ ) decreased significantly $(p<0.05)$ in the presence of Smad3 and TGF $\beta 2$. Smad3 alone or TGF $\beta 2$ and DN-Smad3 did not decrease the Pax3
A

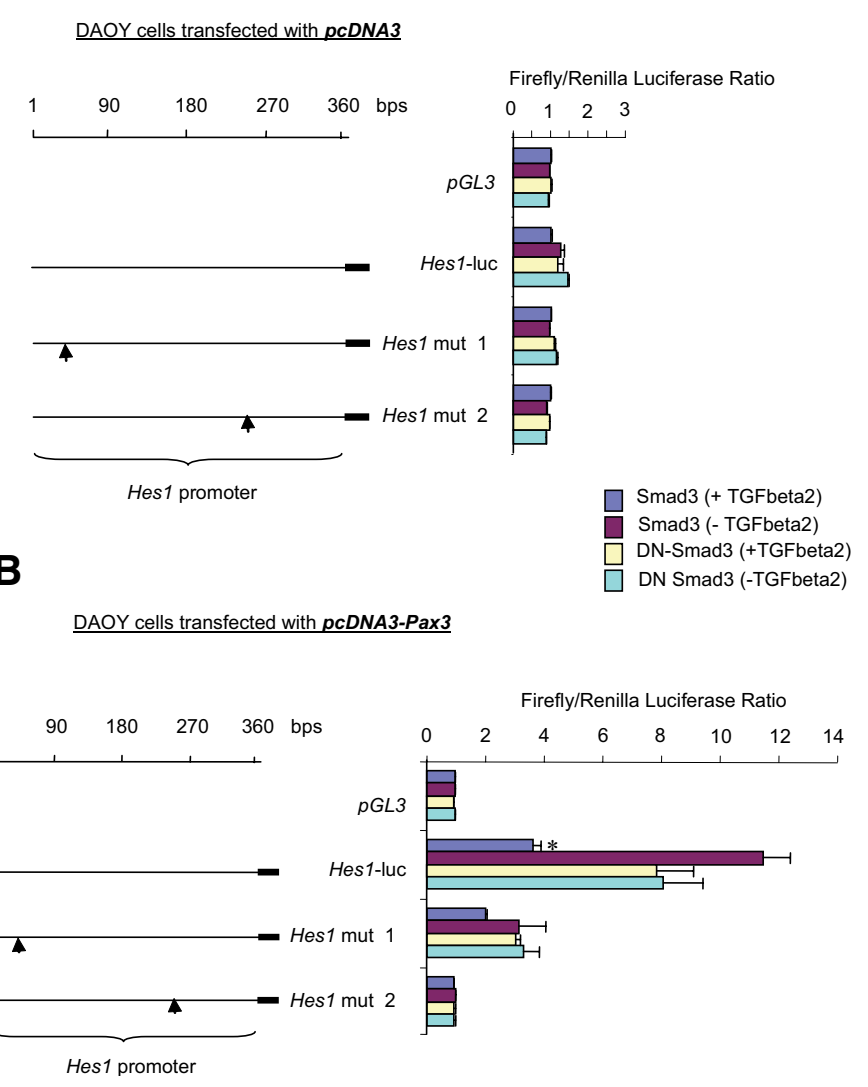

A

DAOY cells transfected with pcDNA3

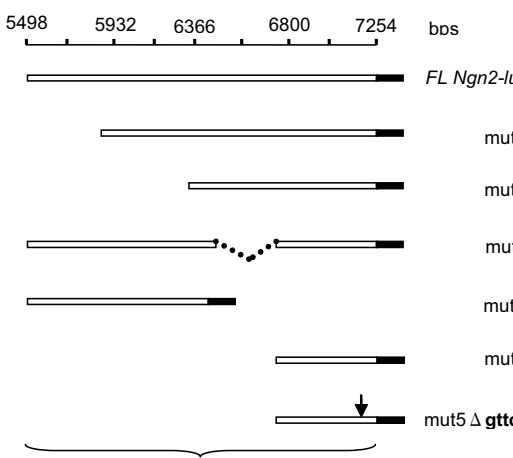

Ngn2 promoter $1.2 \mathrm{~kb}$

B
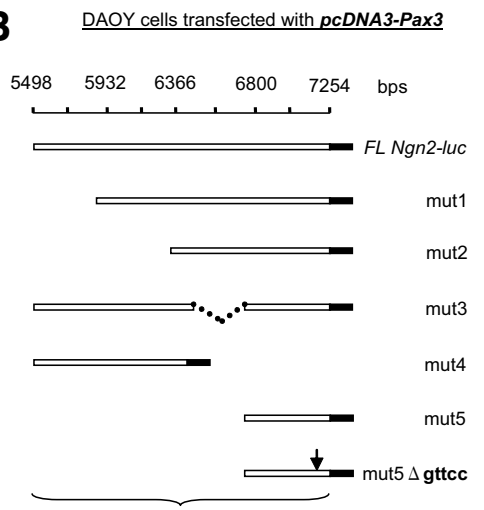

Ngn2 promoter $1.2 \mathrm{~kb}$
Firefly/Renilla Luciferase Ratio

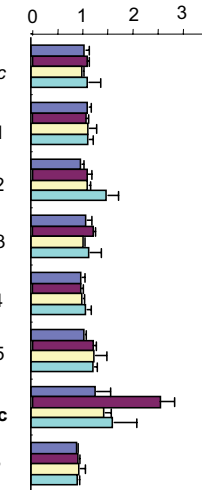

Firefly/Renilla Luciferase Ratio

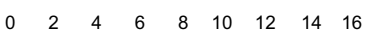

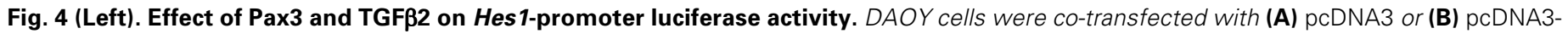

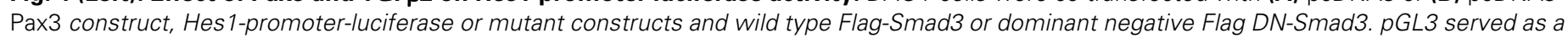

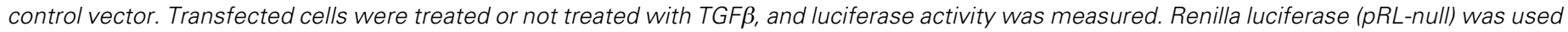

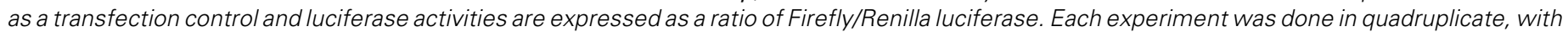

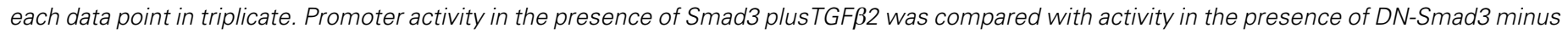
TGF 32 , significance was determined with the Student T test ( $\left.{ }^{*} p<0.05\right)$.

Fig. 5 (Right). Effect of Pax3 and TGFß2 on Ngn2-promoter luciferase activity. DAOY cells were co-transfected with (A) pcDNA3 or (B) pcDNA3Pax3 construct, full length (FL) Ngn2-luciferase or truncated mutant constructs and wild type Flag-Smad3 or dominant negative Flag DN-Smad3. pGL3 served as a control vector. Transfected cells were treated or not treated with TGF 32 and luciferase activity was measured. Renilla luciferase (pRLnull) was used as a transfection control and luciferase activities are expressed as a ratio of Firefly/Renilla luciferase. Each experiment was done 4 times and each data point was in triplicate. Promoter activity in the presence of Smad3 plusTGFB2 was compared with activity in the presence of DN-Smad3 minus TGF 2 , significance was determined with the Student T test $\left({ }^{*} p<0.05 ;{ }^{*} p<0.001\right)$. Key, same as for Fig. 4. 
mediated increase in Hes 1promoter activity. These observations suggest that Hes 1 promoter activity is itself not affected by TGF $\beta 2$, but TGF $\beta 2$ decreases Pax3 induced Hes 1 activity.

Ngn2-promoter-luciferase and mutant constructs are fully described in our previous paper (Nakazaki et al., 2008). When pGL3 control vector, FLNgn2-luc (1.2 kb), mut1, mut2, mut4, mut5, mut5 $\Delta$ gttcc constructs were co-transfected with $p c D N A 3$ in DAOY cells, neither Smad3 nor TGF $\beta 2$ affected promoter activity (Fig. 5A). When FLNgn2-luc was co-transfected with pcDNA3Pax3, with DN-Smad3 minus TGF $\beta 2$, there was a 2 fold increase in promoter activity (Fig. 5B). Pax3 mediated promoter activity was also observed with mut1 (5 fold increase), mut2 (11-12 fold

A

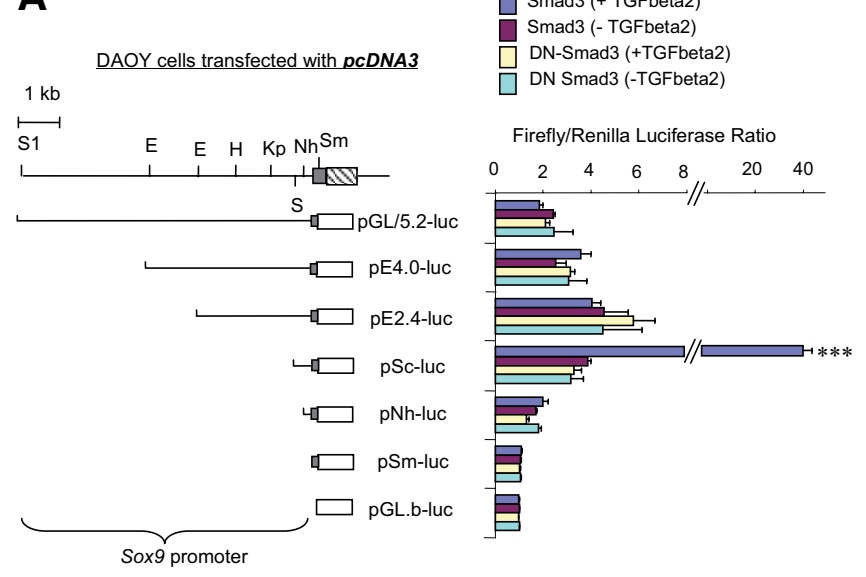

B

DAOY cells transfected with pcDNA3-Pax3

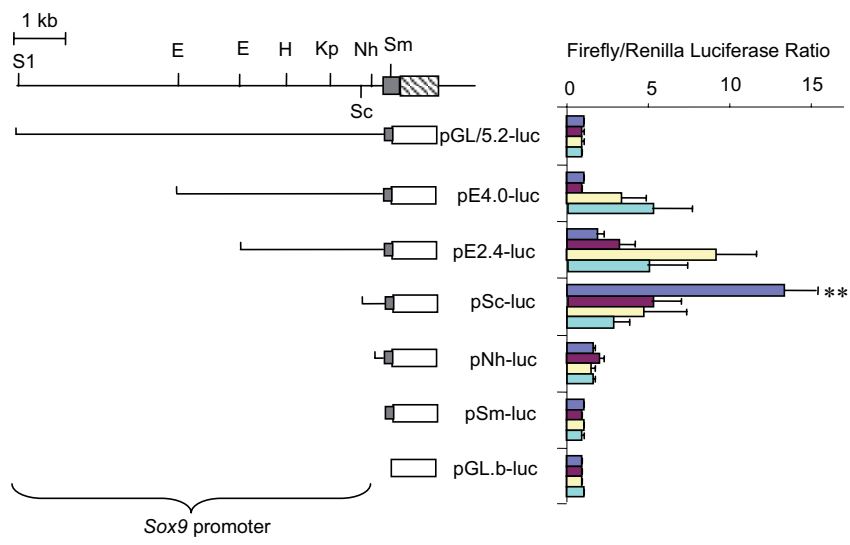

Fig. 6. Effect of Pax3 and TGF $\beta 2$ on Sox9-promoter luciferase activity. DAOY cells were co-transfected with (A) pcDNA3 or (B) pcDNA3Pax3 construct and Sox9-luciferase or truncated mutant constructs, along with wild type Flag-Smad3 or dominant negative Flag DN-Smad3. pGL.b-luc served as a vector. Transfected cells were treated or not treated with TGF 22 and luciferase activity was measured. Renilla luciferase (pRL-null) was used as a transfection control and luciferase activities are expressed as a ratio of Firefly/Renilla luciferase. Each experiment was done in quadruplicate, with each data point in triplicate. Promoter activity in the presence of Smad3 plusTGF $\beta 2$ was compared with activity in the presence of DN-Smad3 minus TGF $\beta 2$, significance was determined with the Student $T$ test $\left({ }^{*} p<0.001 ;{ }^{* * *} p<0.0001\right)$. increase) and mut5 (12-14 fold increase) in the presence of DNSmad3 minus TGF $\beta 2$. These results agree with our previous work (Nakazaki et al., 2008). In the presence of Smad3 plus TGF $\beta 2$, Pax3 mediated promoter activity was decreased in FLNgn2-luc, mut1 $\left({ }^{*} p<0.05\right)$, mut2 $\left({ }^{* *} p<0.001\right)$ and mut5 $\left({ }^{* *} p<0.001\right)$. Smad3 alone or TGF 32 with DN-Smad3 did not decrease Pax3 mediated Ngn2 promoter activity. These observations suggest that Ngn2 promoter activity is itself not affected by TGF $\beta 2$, but TGF $\beta 2$ decreases Pax3 induced Ngn2 activity.

Sox9-luciferase constructs are described in Kanai and Koopman (1999). When pGL.b-luc (control vector), pGL/5.2-luc, pE4.0-luc, pE2.4-luc, pSc-luc, pNh-luc and pSm-luc Sox9 promoter constructs were co-transfected with $p c D N A 3$ (Fig. 6A), there was a significant $(\mathrm{p}<0.0001) \sim 40$ fold increase in Sox9promoter activity with pSc-luc, minimal essential promoter. This increase was not seen with the other three treatment conditions. When Sox9 promoter constructs were co-transfected with pcDNA3-Pax3(Fig. $6 \mathrm{~B})$, with DN-Smad3 minus TGF $\beta 2$, pE2.4-luc, pSc-luc, and pNhluc constructs showed an insignificant increase in promoter activity in comparison to the vector control, suggesting that $\mathrm{Pax} 3$ does not have a direct effect on Sox9 promoter activity. Sox9 promoter may be regulated by genes downstream to Pax3 or coregulators may be required for Sox9promoter regulation. pSc-luc Sox9promoter activity increased $\sim 12$ fold $(\mathrm{p}<0.001)$ as opposed to $\sim 40$ fold when co-transfected with $p c D N A 3$ under the same experimental conditions (Smad3 plus TGF $\beta 2$ ). These studies suggest that although the minimum essential Sox9 promoter is not directly regulated by $\mathrm{Pax} 3$, it is directly up-regulated by $\mathrm{Smad} 3$ plus TGF $\beta 2$. Pax3 may negatively affect this increase.

The data presented in this section suggest Pax3 and TGF $\beta 2$ may reciprocally regulate $\mathrm{Hes} 1, \mathrm{Ngn} 2$ and Sox9promoters during development. These downstream effector genes together with Pax3 and TGF $\beta 2$ may be part of a coordinated gene regulatory network present during neural crest development.

\section{Discussion}

In summary, (a) In TGF 2 nullizygous embryos, down-regulating one allele of Pax3 (as in TGF $32^{--}$Pax $3^{+-}$) can bring about phenotypic reversal of open neural tube. $85 \%$ of TGF $32^{\prime-P a x 3^{+/}}$ ${ }^{+}$E10.0 embryos, but only $36 \%$ of TGF $32^{/-}$Pax $^{+/-}$E10.0 embryos exhibit open neural tube, representing an approximate $60 \%$ success rate in reversing the open neural tube defect. (b) Phenotypic reversal seen in $60 \%$ of $T$ TGF $2^{\prime-P a x} 3^{+/}$embryos is most likely due to differential gene changes, with some genes, possibly including Hes 1, Ngn2 and Sox9, affected by Pax3 and TGF $\beta 2$ in an opposing fashion (Fig. 7). Not all genes will be regulated by these molecules in an opposing fashion, as we did not observe a $100 \%$ phenotypic recovery of the open neural tube defect in $E 10.0$

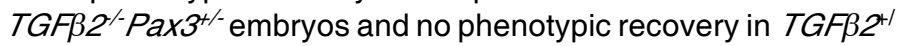
- $P a x 3^{/-}$embryos.

Previous data from our lab on Pax3 regulation of genes (Mayanil et al., 2001) and TGF $\beta$ regulation of genes from Zavadil et al. (2001) supports the fact that these two developmental regulators may act on certain genes in an opposing fashion. Table 2 shows genes that are up-regulated by Pax3 and down-regulated by TGF $\beta 2$, or vice versa. Genes selected for this table from the Mayanil et al. (2001) paper showed at least a 2-fold change in response to Pax3 over-expression in DAOY cells as measured by 


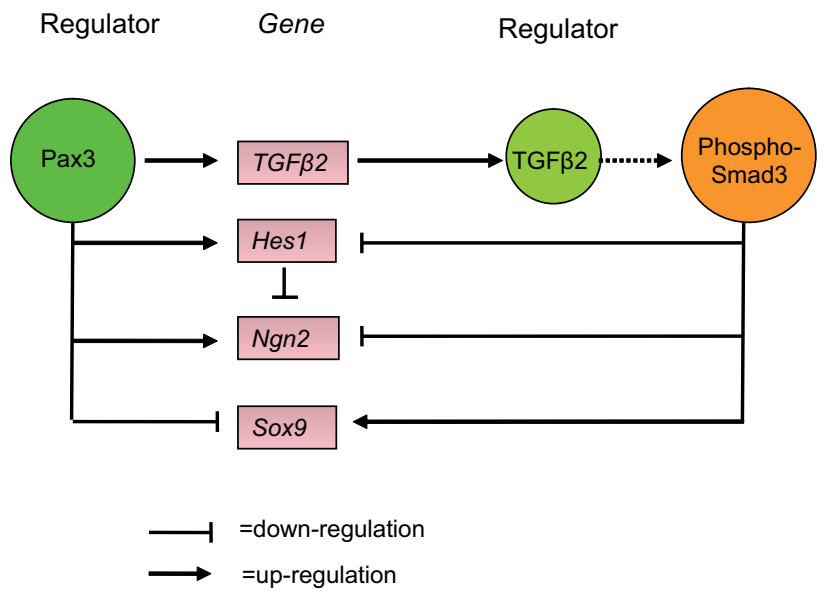

Fig. 7. A hypothetical gene regulatory network comprised of Pax3, TGF及2 and downstream genes, Hes1, Ngn2 and Sox9. Some key neural crest genes such Hes1, Ngn2 and Sox9, may be regulated in an opposing fashion by Pax3 and TGF 32 . Additionally, Hes 1 can negatively regulate Ngn2 expression (Shimojo et al., 2008).

microarray analysis. In the paper by Zavadil et al. (2001) HaCaT keratinocytes were treated for 2 to 4 hours with TGF $\beta$ and gene levels were determined by microarray analysis. Only candidate genes that appear to be regulated in an opposing fashion are shown. Interestingly, Sox4, Sox9(Hong and Saint-Jeannet, 2005) and type IV collagen (Duband and Thiery, 1987), are involved in neural crest development and Rho GDP-dissociation inhibitor (RhoGDI) (Maddala et al., 2008) and tissue inhibitor of matrix metalloprotease 3 ( TIMP3) (DeBecker et al., 2007) are involved in cell migration.

\section{Role of a Pax3/TGFß2 Gene Regulatory Network in neural tube development}

During early embryonic development $\mathrm{Pax} 3$ ensures that NCCs do not execute a differentiation program inappropriate for their dorso-ventral position in the neural tube (Goulding and Lamar, 2000). Previous work from our lab (Nakazaki et al., 2008) has shown that $\mathrm{Pax} 3$ regulates Hes 1 which regulates neural stem cell maintenance and Ngn2 which is involved in neural crest cell neurogenesis (Theriault et al., 2005). Regulation of these molecules may be part of the mechanism by which Pax3 initially maintains neural crest cells in an undifferentiated state prior to migration, and then ensures that positional information is integrated into the neurogenesis process and to the specification of progenitor-cell identity.

Pax3 also regulates TGF 2 (Mayanil et al., 2006), which in turn decreases Pax 3 increased Hes1 and Ngn2 promoter activity. These observations suggest that a coordinated gene regulatory network between Pax3 and TGF $\beta 2$ could play a role in proper timing of neural tube closure and NCC migration. For instance, in the early stages of epithelial to mesenchymal transition (EMT) it may be critical to inhibit Hes1 and Ngn2 without inhibiting Pax3. If $N g n 2$ is not inhibited during early stages of EMT, migratory NCCs may undergo premature sensory neurogenesis and die prior to reaching their destination (Nakazaki etal., 2008). Our data suggests that TGF $\beta 2$ may be an important player in downregulating Ngn2 in the early stages of EMT.
Recently, Shimojo et al. (2008) have shown a complex interaction between Hes1 and Ngn2. This group found that Hes1expression dynamically oscillates in neural progenitors. They also found that Hes 1 oscillations regulate Ngn2 oscillations. Down-regulation of Hes 1expression, which induces neural progenitor differentiation, leads to sustained up-regulation of $\mathrm{Ngn2}$. Our results also suggest a complex relation between Hes1 and Ngn2, with Pax3 and TGF $\beta 2$ playing a role in appropriately timing the expression of these two molecules in NCCs.

Sox9regulation by Pax 3 and TGF $\beta 2$ was also examined in this paper. Sox 9 has a central role in neural crest formation and subsequent EMT and is required for trunk neural crest survival (Sakai et al., 2006). Expression of multiple genes, including Pax3 and Sox9, was downregulated by disrupting Smad 4 in NCCs, thus providing evidence that Smad4-mediated activities of TGF $\beta$ signals are essential for appropriate NCC development (Nie et al., 2008). Our results indicate that $P a x 3$ does not directly affect Sox 9 activity. However, Pax3 may regulate TGF $\beta$ effects on Sox 9 promoter activity. This interaction may play a role in appropriately timing Sox9 expression in NCCs.

Up-regulation of specific genes and delay in others is expected of a cell that is committed to migration. These events prepare the extracellular matrix (ECM) as well as intracellular cytoskeletal elements for efficient migration. Pax3 and TGF $\beta 2$ may also interact in altering levels of various ECM molecules. In a previous study Mayanil et al. (2000) found that Pax3 over-expression upregulated $\alpha-2$, 8-polysialy/transferase (STX), thereby increasing NCAM polysialylation (PSA-NCAM). PSA-NCAM prefers the migration permissive substrate heparin sulfate proteoglycan, whereas Versican, a large chondroitin sulfate proteoglycan (CSPGZ), is a migration non-permissive substrate and promotes NCAM-NCAMmediated homophilic adhesion (Mayanil et al., 2000; Storms and Rutishauser, 1998). Migration of NCCs during early embryonic development would be facilitated if non-permissive substrates were down-regulated. Henderson etal. (1997) observed Versican overexpression in $\mathrm{Pax}^{\%}$ mice, which exhibit defective NCC migration, and suggested that $\mathrm{Pax} 3$ may negatively regulate Versican expression. It is likely that extracellular matrix compo-

TABLE 2

\section{REGULATION OF COMMON DOWNSTREAM GENES BY PAX3 AND TGFB2}

\begin{tabular}{lcc} 
Gene Name & $\begin{array}{c}\text { Gene changes upon } \\
\text { Pax3 over-expression } \\
\text { (Mayanil et al., 2001) }\end{array}$ & $\begin{array}{c}\text { Gene changes upon } \\
\text { TGF } \beta 2 \text { treatment } \\
\text { (Zavadil et al., 2001) }\end{array}$ \\
\hline SOX4 & Decrease & Increase \\
SOX9 & Decrease & Increase \\
Also murine Sox9 (present study) & Decrease & Increase \\
GDP-DISSOCIATION INHIBITOR & Decrease & Increase \\
TYPE IV COLLAGEN & Decrease & Increase \\
UBIQUITIN CONJUGATING ENZYME & Increase & Decrease \\
HES1 (Hairy and Enhancer of Split) & & Decrease \\
Also murine Hes1 (present study) & Increase & Decrease \\
(preferentially expressed antigen of melanoma) & & Decrease \\
37KD LEUCINE RICH REPEAT PROTEIN & Increase & \\
TIMP3 \\
(Tissue inhibitor of matrix metalloproteases3)
\end{tabular}

Evaluation of data from Mayanil et al. (2001) and Zavadil et al. (2001), indicate that TGF $\beta$ negatively regulates certain $\mathrm{Pax} 3$ downstream genes. 


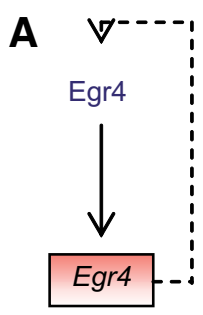

Autoregulation

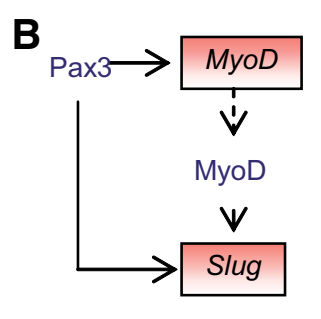

Feed-forward loop

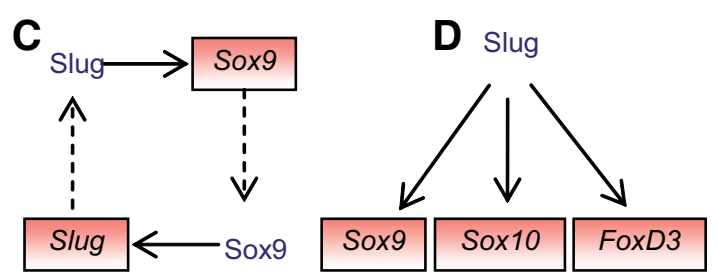

Multi-component loop
Single input motif

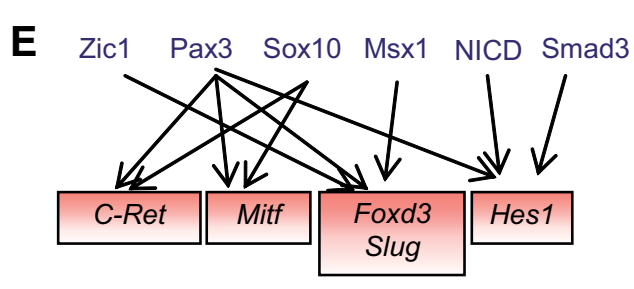

Multi-input motif

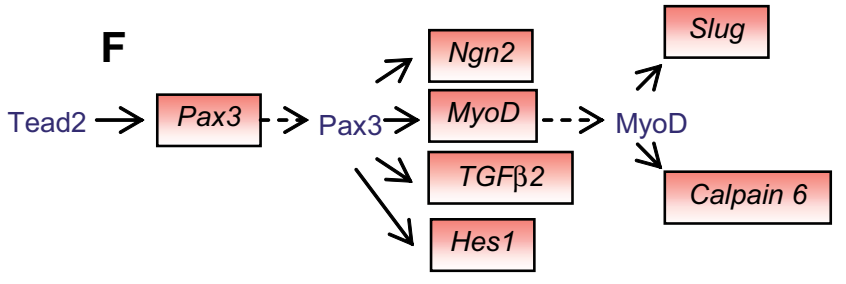

Regulatory chain motif

Fig. 8 . Gene regulatory networks (network motif diagram adapted from Lee et al., 2002, modified for neural crest development). Different network motifs may exist in developing neural crest. (A) Auto-regulation: transcription factor Egr4 acts as an auto-regulatory transcription factor (Zipfel et al., 1997). (B) Feed forward loop: Pax3 regulating MyoD (Tajbakhsh et al., 1997) and MyoD regulating Slug (Zhao et al., 2002). Pax3 also regulating Slug (Monsoro-Burq et al., 2005). (C) Multi-component loop: Slug regulating Sox9 and Sox9 regulating Slug (Meulemans and Bronner-Fraser, 2004). (D) Single input: Slug regulating expression levels of Sox9, Sox10 and FoxD3 (Meulemans and Bronner-Fraser, 2004). (E) Multi-input: seen in neural crest stem cell specifiers: Pax3 and Sox10 regulate c-ret (Lang and Epstein, 2003) and Mitf (Lang et al., 2005). Zic1 and Pax3 regulate Foxd3 and Slug (Meulemans and Bronner-Fraser, 2004), and Smad3 and NICD regulate Hes1 (Blokzijl et al., 2003). (F) Regulatory chain: Tead2 regulating Pax3 (Milewski et al., 2004), Pax3 regulating MyoD among others (Tajbakhsh et al., 1997); MyoD regulating Slug and Calpain 6 (Zhao et al., 2002). Additionally, a regulatory network based on TGF 32 regulation of Slug (Romano and Runyan, 2000) can be constructed by overlapping some of the motifs depicted here.

nents such as Versican V3 are regulated by TGF $\beta 2$, given the fact that several extracellular components that affect cellmatrix interactions are remodeled by TGF $\beta$ for efficient EMT (Zavadil et al., 2001). An unpublished observation from our lab shows that Pax3 down-regulation of Versican V3 (Mayanil et al., 2001) is partially reversed by TGF $\beta 2$ treatment.

A final point in relation to extracellular matrix components is that they could play a key role in making mature TGF $\beta$ available at an appropriate time to induce EMT by negatively regulating Pax3 downstream genes which keep NCCs in a non-migratory state. ECM components and membrane bound forms of TGF $\beta$ co-receptors determine bioavailability of TGF $\beta$ to NCCs (Dijke and Arthur, 2007). Thus TGF $\beta 2$ may be secreted by NCCs, but may not be accessible to interact with its receptors on the membrane because of covalent association with the ECM via latent TGF $\beta$-binding protein (LTBP) (Mangasser-Stephan and Gressner, 1999). However at the critical time, ECM bound large latent TGF $\beta$ complex may be released by matrix metalloproteinases. The released complex may be targeted to the cell surface, and proteolytically activated. Interestingly the expression of tissue inhibitor of matrix metalloprotease 3 (TIMP3), which assists in EMT, is increased by Pax3 overexpression and decreased by TGF $\beta$ treatment (Table 2).

In this paper we have begun to examine the regulatory interaction between Pax3 and TGF $\beta 2$. Pax3 and TGF $\beta 2$ may act as a gene regulatory network in neural tube development and NCC migration. The role of this type of network is to a specify sets of genes that must be expressed in specific spatiotemporal patterns (Meulemans and Bronner-Fraser, 2004). This regulatory network, in turn, is most likely a small part of a larger network involved in the highly complex behavior of neural crest cells. Fig. 8 is an adaptation of a diagram from Lee et al. (2002). We have modified this diagram based on published data to show different types of networks that may exist in developing NCCs. Each of these regulatory motifs in turn, may be building blocks that can be combined into larger network structures.

Further work needs to be done to elucidate the complex relationship between $\mathrm{Pax} 3$ and $\mathrm{TGF} \beta 2$ in regulating gene expression levels in NCCs. Regulation of genes downstream of Pax3 and TGF $\beta 2$ will involve binding of transcription factors, histones, and other transcriptional regulators to the gene's regulatory region. The regulatory region may serve as an integration point, performing a logical computation of transcription factors to determine resulting gene expression levels (Siggia, 2005). Transcriptional regulatory proteins, which recruit and regulate chromatin modifying complexes and components of the transcription apparatus, will recognize specific promoter sequences and in turn affect gene expression programs. For instance, Blumenberg et al. (2007) reported that TGF $\beta$-directed EMT is accompanied by chromatin structure regulation involving Polycomb group epigenetic silencers and histone-lysine methyl transferase EZH1 and EZH2. To add to the complexity, Zavadil et al. (2007) reported TGF $\beta$-directed 
microRNA: mRNA regulatory circuits in EMT. Future studies will examine epigenetic features on promoters of common Pax3 and TGF $\beta 2$ downstream targets, as well as gene expression.

\section{Materials and Methods}

\section{Double heterozygous mouse breeding and genotyping}

The C57BL/6J-Pax3Sp/J (stock = 2469) male and C57BL/6J breeding pairs were obtained from The Jackson Laboratory. Genotyping of

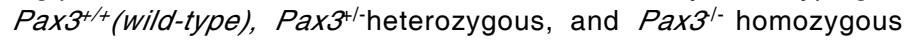
embryos was performed on isolated genomic DNA from embryonic membranes using PCR with a $\mathrm{Pax}^{+/+}$(wild-type) or ( Pax3\%) homozygous specific reverse primer and a common forward primer in separate PCRs as described by Epstein et al. (1996). TGFR2 heterozygous and homozygous genotypes were detected with PCR using the exon 6 primers,

p5 (AATGTGCAGGATAATTGCTGC) and

p3 (AACTCCATAGATATGGGGATGC). The amplification conditions were 35 cycles at $94^{\circ} \mathrm{C}$ for 30 seconds, $57^{\circ} \mathrm{C}$ for 30 seconds and $72^{\circ} \mathrm{C}$ for 90 seconds (Sanford et al., 1997). TGF 2 heterozygous breeding pairs were kindly provided by $\mathrm{Dr}$. T. Doetschman (Sanford et al., 1997) and were used to maintain the TGF 22 heterozygous colony and to obtain TGF 22 nullizygous embryos. Double heterozygous males and females were produced by mating TGF $\beta 2^{\text {t/- }}$ heterozygous females with $\mathrm{Pax}^{+/-}$heterozygous males. The double heterozygous males and females were back-crossed with wild type Swiss black females and males respectively for 6 generations. The resulting double heterozygous males and females were than used to generate the TGF $\beta 2^{\prime-}$ $\mathrm{Pax}^{+/-}$genotypes and other genotypes as per Mendelian projection.

\section{Whole mount in situ hybridization}

Whole mount in situ hybridization was done as described earlier (Mayanil et al., 2006). Washes were performed at $65^{\circ} \mathrm{C}$. The antisense digoxigenin labeled mouse Hes 1 riboprobe was created by linearizing with EcoR1 and synthesized using T7 polymerase. The Hes 1 sense riboprobe was made by, linearizing with $\mathrm{BamH} 1$ and synthesized using T3 polymerase. The antisense digoxigenin labeled mouse Ngn2 riboprobe was created by linearizing with BamH1 and synthesized using T7 polymerase, the Ngn2 sense probe was made by linearizing with EcoR1 and synthesized using SP6 polymerase. The antisense digoxigenin labeled mouse Sox9 riboprobe was created by linearizing with Hind III and synthesized using T7 polymerase. The Sox9 sense riboprobe was made by linearizing with EcoR1 and synthesized using T3 polymerase. Embryos were stained and photographed with a Spot Camera (Diagnostic Instruments Inc.).

Densitometry was performed on appropriate stained areas, using the Open Lab program (Leica). Areas examined were the dorsal neural tube andÄmigratory neural crest cells in Hes 1 riboprobe stained embryos, dorsal and ventral tube regions in Ngn2 riboprobe stained embryos and migratory NCCs in Sox9 riboprobe stained embryos. Staining was quantified from the thoracic/lumbar area downward to include the entire caudal region. On an average, 14-15 somites were counted per embryo of a given genotype. Total density was determined from images scanned in $\mathbf{2 5 6}$ gray scale. The data is represented as the total density ( 8 bit gray), which is defined as the area multiplied by the mean of the relative densitometry units in the field under investigation. Total density of stained NCCs or dorsal or ventral regions of the neural tube were measured, and then the total density of each genotype was averaged. The data is expressed as average density of all embryos (+l - SEM) in each genotype category ( $n=4$ per genotype). Differences between wild type embryos and embryos with other genotypes were compared by subjecting the data to unpaired T-Test with two-tailed $P$ value (Graph Pad PRISM 4). The data is expressed as the average density of all embryos ( $n=4$ per genotype).

\section{Analysis of Hes1, Ngn2 and Sox9 promoter activity in the presence and absence of TGF $\beta 2$}

Constructs were kindly provided by: Hes1-promoter luciferase construct, Dr. R. Kageyama, Ngn2-promoter (AF303001) promoter luciferase constructs, Dr. J. Johnson, Sox9-promoter luciferase constructs Dr. P. Koopman. Hes1- and Ngn2-luciferase and their mutant constructs are fully described in our earlier work (Nakazaki et al., 2008). Sox9-luciferase and its mutant constructs are described in Kanai and Koopman (1999). Each of these constructs $(0.2 \mu \mathrm{g})$ were transiently co-transfected into DAOY cells with Pax3-pcDNA3or pcDNA3 vector control and Flag-Smad3 wild type $(0.2 \mu \mathrm{g})$ or dominant negative Flag-DN-Smad3 $(0.2 \mu \mathrm{g})$ cloned in HSV-TK-pEXL vector (kindly provided by Dr. H. F. Lodish, MIT). DAOY cells were used to maintain consistency with previous experiments done in our laboratory (Mayanil et al., 2000; 2001; 2006 and Nakazaki et al., 2008). 24 hrs posttransfection, transfected DAOY cells were treated or not treated with $10 \mathrm{ng} / \mathrm{ml}$ human recombinant TGF $\beta 2$ for $6 \mathrm{hrs}$. Luciferase activity was measured 48 hrs post-transfection using the Dual Luciferase Kit from Promega, as previously described (Mayanil et al., 2006). Transfected cells not treated with TGF $\beta 2$ served as the negative control.

\section{Comparison of common downstream genes regulated by Pax3 or TGF $\beta 2$}

Microarray data from Mayanil et al. (2001) and Zavadil et al. (2001) were compared. Examination of 270 genes altered by Pax3, as examined in Pax3 stably transfected DAOY cells (Mayanil et al., 2001), and 728 genes, in $\mathrm{HaCaT}$ keratinocytes, altered by 2 to 4 hour treatment with TGF $\beta$ (Zavadil et al., 2001), yielded 58 genes that were altered in both studies. To increase stringency 2 fold or higher increase or decrease in expression levels was used as a cut off. This resulted in a total of 22 genes altered by both Pax3 overexpression and TGF $\beta$ treatment. From these 22, 10 candidate genes, 5 up-regulated and 5 down-regulated by Pax3 (Mayanil et al., 2001) and oppositely regulated by TGF $\beta$ treatment (Zavadil et al., 2001) are shown in Table 2. Out of these 10 genes, we used three for our in situ hybridization and promoter-luciferase studies. Several genes not listed in Table 2 did show up-regulation or down-regulation in response to both $\mathrm{Pax} 3$ overexpression and TGF $\beta$ treatment.

\section{Acknowledgements}

The authors would like to thank Dr. P. Gruss Max Planck Institute, Gottingen, Germany, for the pBH3.2 plasmid containing Pax3; Dr. N. L Brown, Division of Developmental Biology, Departments of Pediatrics and Ophthalmology, University of Cincinnati College of Medicine, Cincinnati, OH, USA, for pBluescriptHes 1 and p GEM3Ngn2 plasmids; Dr. de Crombrugghe, University of Texas, MD Anderson Cancer Center, and Department of Molecular Genetics, Houston Texas for murine Sox9 CDNA probe. TGF $32^{+/-}$heterozygous breeding pairs were provided by Dr. T. Doetschman, Department of Molecular Genetics, Biochemistry and Microbiology, University of Cincinnati, Ohio. The authors also wish to thank Dr. R. Kageyama, Institute for Virus Research, Kyoto University for Hes 1-promoter luciferase constructs; Dr. J. Johnson, Department of Neuroscience, University of Texas Southwestern Medical Center, Dallas, TX for Ngn2-promoter-luciferase constructs; and Dr. P. Koopman, Division of Molecular Genetics and Development, Institute for Molecular Bioscience, The University of Queensland, Brisbane, Australia for Sox9-promoter-luciferase constructs. The Flag-Smad3 and Flag-DN-Smad3 constructs were gifts from Dr H.F. Lodish, Whitehead Institute for Biomedical Research, Department of Biology, Massachusetts Institute of Technology. The authors also wish to thank Dr. J. A. Kessler, Feinberg School of Medicine, Northwestern University, and Dr. S. Ahlgren Developmental Biology Program, Childrens Memorial Research Center, Chicago for valuable discussions, $\mathrm{Dr} \mathrm{H}$. Chung for statistical assistance and Bill Goossens for microscope assistance. This work was supported by the 
State of Illinois Excellence in Academic Medicine award (CSKM) and a Grant from the Spastic Paralysis Research Foundation of IllinoisEastern lowa District of Kiwanis (CSKM and DGM). The earlier preliminary part of the work described in this paper was done in the Neurobiology Program at Childrens Memorial Research Center, Chicago, IL 60614.

\section{References}

AUERBACH, R. (1954). Analysis of the developmental defects of a lethal mutation in the house mouse. J. Exp. Zool. 127: 305-329.

BLOKZIJL, A., DAHLQVIST, C., REISSMANN, E., FALK, A., MOLINER, A., LENDHAL, U. and IBANEZ, C. F. (2003). Cross-talk between Notch and TGF $\beta 2$ signaling pathways mediated by interaction of Notch intracellular domain with Smad3. J. Cell. Biol. 163: 723-728.

BLUMENBERG, M., GAO, S., DICKMAN, K., GROLLMAN, A. P., BOTTINGER, E. P. and ZAVADIL, J. (2007). Chromatin structure regulation in transforming growth factor-beta-directed epithelial-mesenchymal transition. Cells Tissue Organs 185:162-174.

CHEUNG, M. and BRISCOE, J. (2003). Neural crest development is regulated by the transcription factor Sox9. Development 130:5681-5693.

DEBECKER, A., VAN HUMMELEN, P., BAKKUS, M., VANDE BROEK, I., DE WEVER, J., DE WAELE, M., VAN RIET, I. (2007). Migration of cultureexpanded human mesenchymal stem cells through bone marrow endothelium is regulated by matrix metalloproteinase-2 and tissue inhibitor of metalloproteinase-3. Haematologica 92: 440-449.

DIJKE P. T. and ARTHUR, H. M. (2007). Extracellular control of TGF $\beta$ signaling in vascular development and disease. Nature Rev Mol. Cell. Biol. 7: 857-869.

DUBAND, J. L. and THIERY, J. P. (1987). Distribution of laminin and collagens during avian neural crest development. Development 101: 461-478.

EPSTEIN, D. J. VEKEMANS, M. and GROS, P. (1991). Splotch ( $S p 2 H)$, a mutation affecting development of the mouse neural tube, shows a deletion within the paired homeodomain of Pax-3. Cel/67: 767-774.

EPSTEIN, J. A., SHAPIRO, D. N., CHENG, J., LAM, P. Y. P. and MAAS, R. L. (1996). Pax3 modulates expression of the C-Met receptor during limb muscle development. J. Biol. Chem. 93: 4213-4218.

FODE, C., GRADWOHL, G., MORIN, X., DIERICH, A., LEMEUR, M., GORIDIS, C. and GUILLEMOT, F. (1998). The bHLH protein NEUROGENIN2 is a determination factor for epibranchial placode-derived sensory neurons. Neuron 20: 483-494.

FOY, C., NEWTON, V., WELLESLEY, D., HARRIS, R. and READ, A. P. (1990). Assignment of the locus for Waardenburg syndrome type I to human chromosome 2q37 and possible homology to the Splotch mouse. Am. J. Hum. Genet. 46:1017-1023.

GARCÍA-CAMPMANY, L. and MARTÍ, M. (2007). The TGF $\beta$ intracellular effector Smad3 regulates neuronal differentiation and cell fate specification in the developing spinal cord. Development 134: 65-75.

GOULDING, M. D., CHALEPAKIS, G., DEUTSCH, U., ERSELIUS, J. R. and GRUSS, P. (1991). Pax-3, a novel murine DNA binding protein expressed during early neurogenesis. EMBO J. 10: 1135-1147.

GOULDING, M. D., STERRER, S., FLEMING, J., BALLING, R., NADEAU, J., MOORE, K. J., BROWN, S., STEEL, K. P. and GRUSS, P. (1993). Analysis of the Pax-3 gene in the mouse mutant splotch. Genomics 17: 355-363.

GOULDING, M. and LAMAR, E. (2000). Neuronal patterning: Making stripes in the spinal cord. Curr. Biol. 10:R565-R658.

HENDERSON, D. J., YBOT-GONZALEZ, P. and COPP, A. J. (1997). Overexpression of the chondroitin sulphate proteoglycan Versican is associated with defective neural crest migration in the Pax3 mutant mouse (splotch). Mech. Dev. 69: 39-51.

HIRATA, H., TOMITA, K., BESSHO, Y. and KAGEYAMA, R. (2001). Hes1 and Hes3 regulate maintenance of the isthmic organizer and development of the mid/ hindbrain. EMBO J. 20: 4454-4466.

HIRATA, H., YOSHIURA, S., OHTSUKA, T., BESSHO, Y., HARADA, T., YOSHIKAWA, K. and KAGEYAMA, R. (2002). Oscillatory expression of the bHLH factor Hes1 regulated by a negative feedback loop. Science 298: 840-
843.

HONG, C. S., and SAINT-JEANNET, J. P. (2005). Sox proteins and neural crest development. Seminars in Cell and Dev. Biol. 16: 694-703.

HOSOKAWA, R., URATA, M., HAN, J., ZEHNALY, A., BRINGAS, P JR, NONAKA, $\mathrm{K}$., and CHAI, Y. (2007). TGF-beta mediated Msx2 expression controls occipital somites-derived caudal region of skull development. Dev. Biol. 310: 140-153.

KANAI, Y., and KOOPMAN, P. (1999). Structural and functional characterization of the mouse Sox9 promoter: implications for campomelic dysplasia. Hum. Mol. Genet. 8: 691-696.

LANG, D. and EPSTEIN, J. A. (2003). Sox10 and Pax3 physically interact to mediate activation of a conserved c-RETenhancer. Hum. Mol. Genet. 12: 937945.

LANG, D., LU, M. M., HUANG, L., ENGLEKA, K. A., ZHANG, M., CHU, E. Y., LIPNER, S., SKOULTCHI, A., MILLAR, S. E. and EPSTEIN, J. A. (2005). Pax3 functions at the nodal point in melanocyte stem cell differentiation. Nature 433: 884-887.

LEE, T. I., RINALDI, N. J., ROBERT, F., ODOM, D. T., BAR-JOSEPH, Z., GERBER, G. K., HANNETT, N. M., SIMAON, I., ZEITLINGER, J., JENNINGS, E. G., MURRAY, H. L., GORDON, D.B., REN, B., WYRICK, J. J., TAGNE, J-B., VOLKERT, T. L., FRAENKEL, E., GIFFORD, D. K. and YOUNG, R. A. (2002). Transcriptional Regulatory networks in Saccharomyces cerevisiae. Science 298: 799-804.

LI, J., LIU, K. C., JIN, F., LU, M. M. and EPSTEIN, J. A. (1999). Transgenic rescue of congenital heart disease and spina bifida in Splotchmice. Development 126: 2495-503.

LO, L., DORMAND, E., GREENWOOD, A., and ANDERSON, D. J. (2002). Comparison of the generic neuronal differentiation and neuron subtype specification functions of mammalian achaete-scute and atonal homologs in cultured neural progenitor cells. Development 29: 1553-1567.

MADDALA, R., RENEKER, L. W., PENDURTHI, B., and RAO, P. V. (2008). Rho GDP dissociation inhibitor-mediated disruption of Rho GTPase activity impairs lens fiber cell migration, elongation and survival. Dev. Biol. 315: 217-231.

MANGASSER-STEPHAN, K. and GRESSNER, A. M. (1999). Molecular and functional aspects of latent transforming growth factor-beta binding protein: just a masking protein? Cell Tissue Res. 297: 363-370.

MAYANIL, C. S. K., GEORGE, D., MANIA-FARNELL, B., BREMER, C. L., MCLONE, D. G. and BREMER, E. G. (2000). Overexpression of murine Pax3 increases NCAM polysialylation in a human medulloblastoma cell line. J. Biol. Chem. 275: 23259-23266.

MAYANIL, C. S. K., GEORGE, D., FREILICH, L., MILJAN, E. J., MANIA-FARNELL., MCLONE, D. G. and BREMER, E. G. (2001). Microarray analysis detects novel Pax3 downstream target genes. J. Biol. Chem. 52: 49299-49309.

MAYANIL, C. S. K., POOL, A., NAKAZAKI, H., REDDY, A., MANIA-FARNELL, B., YUN, B., GEORGE, D., MCLONE, D. G. and BREMER, E. G. (2006). Regulation of murine TGF $\beta 2$ by Pax3 during early embryonic development. J. Biol. Chem. 281: 24544-24552.

MEULEMANS, D. and BRONNER-FRASER, M. (2004). Gene-regulatory Interactions in neural crest evolution and development. Developmental Cel/7: 291299.

MILEWSKI, R. C, CHI, N. C., LI, J., BROWN, C., LU, M. M. and EPSTEIN, J. A. (2004). Identification of minimal enhancer elements sufficient for Pax3 expression in neural crest and implication of Tead2 as a regulator of Pax3. Development 131:829-837.

MONSORO-BURQ, A-H., WANG, E. and HARLAND, R. (2005). Msx1 and Pax3 cooperate to mediate FGF8 and Wnt signals during Xenopus neural crest induction. Developmental Cel/8: 167-178.

NAKAZAKI, H., REDDY, A., MANIA-FARNELL, B., YUEH-WEI, S., MCCABE C., ICHI, S., GEORGE, D., MCLONE, D. G., TOMITA, T. and MAYANIL, C. S. K. (2008). Key basic helix loop helix transcription factor genes Hes 1 and Ngn2are regulated by Pax3 during mouse embryonic development. Dev. Biol. 316: 510523.

NIE, X., DENG, C. X., WANG, Q. and JIAO, K. (2008). Disruption of Smad4 in neural crest cells leads to mid-gestation death with pharyngeal arch, craniofacial and cardiac defects. Dev. Biol. 316: 417-430.

ROMANO, L. and RUNYAN, R. B. (2000). Slug is an essential target of TGFß2 signaling in the developing chicken heart. Dev. Biol. 223: 91-102. 
SAKAI, D., SUZUKI, T., OSUMI, N., and WAKAMATSU, Y. (2006). Cooperative action of Sox9, Snail2 and PKA signaling in early neural crest development. Development 133:1323-1333.

SANFORD, L. P., ORMSBY, I., GITTENBERGER-DE GROOT A. C., SARIOLA, H., FRIEDMAN, R., BOIVIN, G. P., CARDELL, E. L. and DOETSCHMAN, T. (1997). TGFbeta2 knockout mice have multiple developmental defects that are nonoverlapping with other TGFbeta knockout phenotypes. Development 124: 2659-2670.

SHIMOJO, H., OHTSUKA, T. and KAGEYAMA, R. (2008). Oscillations in Notch Signaling Regulate Maintenance of Neural Progenitors. Neuron 58: 52-64.

SIGGIA, E. D. (2005). Computational methods for transcriptional regulation. Curr. Opin. Genet. Dev. 15: 214-221.

SIMMONS, A. D., HORTON, S., ABNEY, A. L. and JOHNSON, J. E. (2001). Neurogenin2 expression in ventral and dorsal spinal neural tube progenitor cells is regulated by distinct enhancers. Dev. Biol. 229: 327-339.

STORMS, S. D. and RUTISHAUSER, U. (1998). A role for polysialic acid in neural cell adhesion molecule heterophilic binding to proteoglycans. J. Biol. Chem. 273: 27124-27149.

TAJBAKHSH, S., ROCANCOURT, D., COSSU, G. and BUCKINGHAM, M. (1997).
Redefining the genetic hierarchies controlling skeletal myogenesis: Pax-3 and Myf-5 act upstream of MyoD. Ce//89: 127-138.

THERIAULT, F. M., NUTHALL, H. N., DONG, Z., LO, R., BARNABE-HEIDER, F., MILLER, F. D. and STIFANI, S. (2005). Role for Runx1 in the proliferation and neuronal differentiation of selected progenitor cells in the mammalian nervous system. J. Neurosci. 25: 2050-2061.

ZAVADIL, J., BITZER, M., LANG, D., YANG, Y-C., MASSIMI, A., KNEITZ, S., PIEK, E. AND BOTTINGER, E.P. (2001). Genetic programs of epithelial cell plasticity directed by transforming growth factor- $\beta$. Proc. Natl. Acad. Sci. (USA)98: 66866691.

ZAVADIL, J., NARASIMHAN, M., BLUMENBERG, M. and SCHNEIDER, R. J. (2007). Transforming growth factor-beta and microRNA: mRNA regulatory networks in epithelial plasticity. Cells Tissues Organs 185: 157-161.

ZHAO, P., IEZZI, S., CAVER, E., DRESSMAN, D., GRIDLEY, T., SARTORELLI, V. and HOFFMAN, E. P. (2002). Slug is a novel downstream target of MyoD: Temporal profiling in muscle regeneration. J. Biol. Chem. 277: 30091-30101.

ZIPFEL, P. F., DECKER, E. L., HOLST, C. and SKERKA, C. (1997). The human zinc finger protein EGR-4 acts as auto regulatory transcriptional repressor. Biochim. Biophys. Acta 1354: 134-144. 


\section{Further Related Reading, published previously in the Int. J. Dev. Biol.}

See our Special Issue The Nogent Institute in honor of Nicole Le Douarin and edited by Francoise Dieterlen at: http://www.ijdb.ehu.es/web/contents.php?vol=49\&issue=2-3

See our recent Special Issue Fertilization, in honor of David L. Garbers and edited by Paul M. Wassarman and Victor D. Vacquier at: http://www.ijdb.ehu.es/web/contents.php?vol=52\&issue=5-6

Epithelial-Mesenchymal Transitions in development and disease: old views and new perspectives M. Angela Nieto Int. J. Dev. Biol. In Press doi: 10.1387/ijdb.072410mn

Perichondrial-mediated TGF-beta regulation of cartilage growth in avian long bone development Marsha L. Crochiere, James K. Kubilus and Thomas F. Linsenmayer Int. J. Dev. Biol. (2008) 52: 63-70

Equivalent genetic regulatory networks in different contexts recover contrasting spatial cell patterns that resemble those in Arabidopsis root and leaf epidermis: a dynamic model Mariana Benítez, Carlos Espinosa-Soto, Pablo Padilla-Longoria, José Díaz and Elena R. Alvarez-Buylla Int. J. Dev. Biol. (2007) 51: 139-155

Comparative expression analysis of $\mathrm{Pax} 3$ and $\operatorname{Pax} 7$ during mouse myogenesis David Horst, Svetlana Ustanina, Consolato Sergi, Gregor Mikuz, Herbert Juergens, Thomas Braun and Eugene Vorobyov Int. J. Dev. Biol. (2006) 50: 47-54

Genetic interaction between Lef1 and Alx4 is required for early embryonic development

Kata Boras-Granic, Rudolf Grosschedl and Paul A. Hamel Int. J. Dev. Biol. (2006) 50: 601-610

Long-range signalling in plant reproductive development Paula Suárez-López

Int. J. Dev. Biol. (2005) 49: 761-771

Gene network analysis in plant development by genomic technologies Frank Wellmer and José Luis Riechmann Int. J. Dev. Biol. (2005) 49: 745-759

Historical perspectives on plant developmental biology Mieke Van Lijsebettens and Marc Van Montagu Int. J. Dev. Biol. (2005) 49: 453-465

Contributions by members of the TGFbeta superfamily to lens development David Beebe, Claudia Garcia, Xiaohui Wang, Ramya Rajagopal, Mary Feldmeier, JiYoung Kim, Anna Chytil, Harold Moses, Ruth Ashery-Padan, and Michael Rauchman Int. J. Dev. Biol. (2004) 48: 845-856

Developmental gene network analysis.

Roger Revilla-i-Domingo and Eric H Davidson

Int. J. Dev. Biol. (2003) 47: 695-703

Transcriptional regulation and the evolution of development. Gregory A Wray Int. J. Dev. Biol. (2003) 47: 675-684

Evolution of cis-regulatory regions versus codifying regions. Francisco Rodríguez-Trelles, Rosa Tarrío and Francisco J Ayala Int. J. Dev. Biol. (2003) 47: 665-673

Developmental basis for vein pattern variations in insect wings. José $\mathrm{F}$ De Celis and Fernando J Diaz-Benjumea Int. J. Dev. Biol. (2003) 47: 653-663

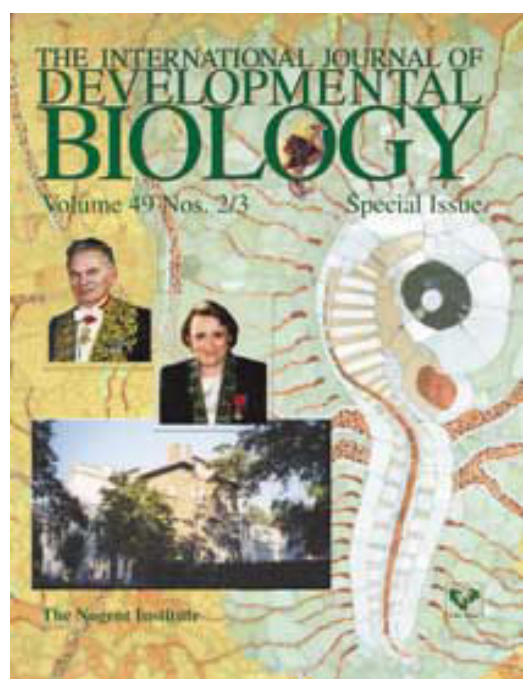

2006 ISI **Impact Factor $=3.577^{* *}$

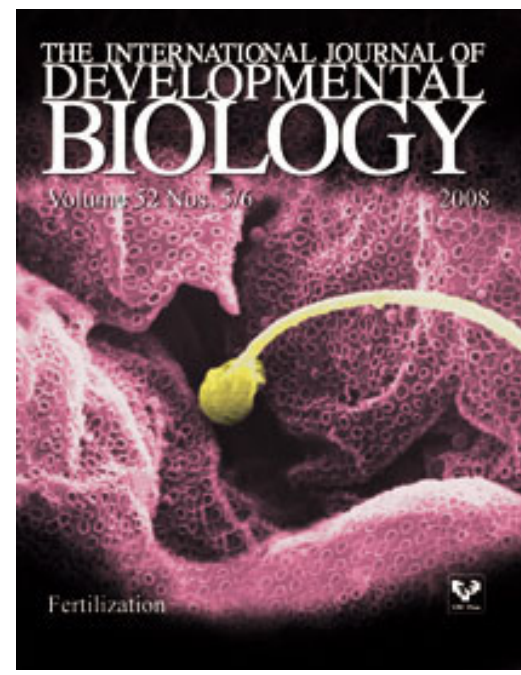

